Vol. 44, N. 1 : pp. 69 - 78, March, 2001

ISSN 1516-8913 Printed in Brazil
BRAZILIAN ARCHIVES OF BIOLOGY AND TECHNOLOGY

AN INTERNATIONAL JOURNAL

\title{
Characterization of Chestnut (Castanea sativa, Mill) Starch for Industrial Utilization
}

\author{
Ivo Mottin Demiate ${ }^{1}$, Marília Oetterer ${ }^{2}$ and Gilvan Wosiacki ${ }^{1}$ \\ ${ }^{1}$ Departamento de Zootecnia e Tecnologia de Alimentos, Setor de Ciências Agrárias e de Tecnologia,Universidade \\ Estadual de Ponta Grossa - UEPG, Praça Santos Andrade, s/n, CEP 84.010-330 Ponta Grossa PR Brasil; \\ ${ }^{2}$ Departmento de Ciência e Tecnologia Agroindustrial, Escola Superior de Agricultura Luiz de Queiroz-ESALQ, \\ Universidade de São Paulo - USP, Piracicaba SP Brasil.
}

\begin{abstract}
Studies were conducted to characterize the chestnut and its starch. Chemical composition of the chestnuts showed high level of starch. Moisture level in the raw nuts was around $50 \mathrm{~g} / 100 \mathrm{~g}$ in wet basis and starch content, around $80 \mathrm{~g} / 100 \mathrm{~g}$ in dry basis; other nut flour components were protein $(5.58 \mathrm{~g} / 100 \mathrm{~g})$, lipid $(5.39 \mathrm{~g} / 100 \mathrm{~g})$, crude fiber (2.34 $\mathrm{g} / 100 \mathrm{~g})$ and ash $(2.14 \mathrm{~g} / 100 \mathrm{~g})$. Starch fraction was chemically characterized in order to identify the granule quality as compared with those of cassava and corn. This fraction showed more lipids and proteins than the other starches. Chestnut starch granules showed peculiar shape, smaller than the control starches and low amount of damaged units. Chemical composition concerning amylose : amylopectin ratio was intermediate to that presented by cassava and corn starch granules. Water absorption at different temperatures as well as solubility were also intermediate but closer to that presented by cassava granules. The same behavior was observed in the interaction with dimethylsulfoxide. Native starch granules and those submitted to enzymatic treatment with commercial a-amylase and also with enzymes from germinated wheat were observed by scanning electronic microscopy. Water suspensions of chestnut starch granules were heated to form pastes that were studied comparatively to those obtained with cassava and corn starches. Viscographic pattern of chestnut starch pastes showed a characteristic profile with high initial viscosity but peak absence, high resistance to mechanical stirring under hot conditions and high final viscosity. There was no way to compare it with the paste viscographic profiles obtained with the control starches. Chestnut starch pastes were stable down to $\mathrm{pH} 4$ but unstable at pH 3. The water losses observed in the chestnut starch pastes after freeze-thaw cycles showed more similarity to the pattern observed in corn starch pastes as well as clarity and strength of the gel. In general the results showed that chestnut pastes functional properties are intermediate to those of the cassava and corn starch pastes.
\end{abstract}

Key words: Castanea sativa, Starch, Granules, Pastes, Sweet Chestnut, Cassava

\section{INTRODUCTION}

European chestnut trees spread all over the world produce wood and chestnuts that have considerable economical value. Specific literature describes some utilization for chestnuts in Europe being emphasized the marron glace production; some references also relate their use in baking, mainly under economically difficult condition (Brouk, 1975). In Brazil, however, they are not products of economic interest: trees are grown for their landscape qualities in many farms and also in

* Author for correspondence 
some public squares, mainly in Southern Region. Their harvest is expensive and there are not organized orchards with economical purposes. European, Spanish, Portuguese or sweet chestnuts are the seeds, annually produced inside spiny, dehiscent fruits, that easily fall down from the trees. These seeds rapidly dehydrate and as the germ dies, the decomposition processes are accelerated.

Chemical composition of the chestnuts reveals starch as the main component but more scientific information is quite difficult to be found. In general the literature deals with agricultural features of the trees, especially concerning phytopathology (Izquierdo, 1978; Rutter et al., 1991).

Studies on new natural starches are essential for their best use and also to increase the utilization of starchy flours. Modi \& Kulkarni (1976), searching for new indigenous sources of starch, studied characteristics of Amaranthus paniculatus (L.) starch while Wankhede et al. (1977) studied extraction and properties of starch from groundnut seeds. Park et al. (1982) and Takeda et al. (1987) studied some characteristics of Chinese chestnut (Castanea crenata) starch. Hatanaka et al. (1997) isolated and described some properties of starch from halotolerant microalgae Dunaliella and examined its starch value as food resource.

The development of new functional raw materials for use in food industry was considered by Loesche (1990), with reference to various products which could be incorporated into food to improve quality or hygienic characteristics; among the raw material new starches were included. Several reports dealt with the development of new starches for the food industry (Alexander, 1996; Mauro, 1996; Stockwell, 1995). Patil (1994) and Alexander (1996) studied functional properties of starches from new corn hybrids and considered their uses in foods in order to replace chemically modified starches. The hybrids contain different levels of straight-chained amylose and branched amylopectin.

Development of new starches employing genetic manipulation of corn hybrids by the introduction of multiple genes into plants (Technology-Assisted Breeding) was discussed by Stockwell (1995). There are also several papers about new starches with desired functional properties for tilization in food industry (Smith \& Bell, 1986; Zallie, 1988); discovering and developing new starches is a key for reducing costs at the confectioner industry (Smith, 1975).

Starch versatility as a food ingredient was stressed and sensory effects of starches from different corn hybrids studied by Hippleheuser (1994); it was concluded that inherent differences in a starch system contribute to differences in flavor enhancement and/or flavor masking.

New modified starches with well defined functional properties were developed for food application; as an example, a series of starches with improved lipophylic properties have been designed for use in producing salad dressing; high viscosity, smooth texture, low acidity and in some cases mayonnaise-like character are examples of other properties developed (American Maize Products Co., 1983).

Starch itself, for utilization as an additive in food industry or even for biotechnological use as an energetic component of fermentation media, must be well characterized due to economical and technological aspects. A special research field is the modification of starches by physical, chemical or other methods, as the microbiological modification employed in cassava sour starch (polvilho azedo) production in South America, especially in Brazil, where this starch is employed for production of gluten-free baked foods. Mestres et al. (1996) produced corn-fermented starch and compared its properties with that of the cassava sour starch. Rheological features are quite different considering starches of other sources and generally their functional properties determine industrial uses. In the present paper, European chestnut starch granules and pastes are considered in comparison with control starches, namely corn and cassava.

\section{MATERIAL AND METHODS}

Chestnuts. Samples of the spiny fruits containing seeds were collected from trees growing in farms in South Brazil, nearby the tropic of Capricorn. The seeds were removed manually from the fruits, peeled and processed. Commercial grade corn and cassava starches were used as standards when necessary. The seeds were evaluated in terms of weight, diameter, moisture content and proportions between edible and non-edible parts considering 70 samples. Moisture content was determined by dehydration in an electric oven at $104^{\circ} \mathrm{C}$ until constant weight (AOAC, 1965). 
Chestnut Flour. The flour was obtained by dry milling the dehydrated seeds and sieving (60 USBS). Dry matter content, starch, protein, lipid, fiber and ash were determined according to official methods (AOAC, 1965).

Chestnut Starch. Starch was obtained as a precipitate in water after peeling, grinding, drying, milling and sieving (325 USBS). A chemical treatment with $0.15 \mathrm{~N} \mathrm{NaOH}$ was carried out for its purification (Wosiacki \& Cereda, 1985; 1989; Cereda \& Wosiacki, 1985).

Starch natural fermentation. A sample of chestnut starch was allowed to ferment during 30 days at room temperature; starter culture was a small sample of polvilho azedo. Description of the entire process is available in the literature (Demiate et al., 1997a, 1997b). The fermented product, after sun drying, was evaluated for swelling power and solubility.

Starch chemical characterization. The analysis included dry matter, starch, protein, lipid, fiber and ash determinations (AOAC, 1965).

Amylose and amylopectin contents. Amylose content was determined spectrophotometrically by the reaction with iodine and calculated based on the blue value - BV (Morrison \& Laignelet, 1983).

Granules microscopy. Photomicrographs from small samples fixed with ethanol on a metallic support were taken in a Phillips 505 scanning electronic microscope - SEM; samples included granular starch before and after enzymatic digestion with commercial grade $\alpha$-amylase or germinated wheat extract. Samples were photographed at a magnification of 2,020 times.

Granule susceptibility to dimethylsulfoxide (DMSO). After a 30 hours DMSO treatment (Leach \& Schoch, 1962), solubilization degree was calculated based on total (Dubois et al, 1956) and reducing (Somogyi, 1945 as modified by Nelson, 1944) sugar present in the supernatant after a 15 min centrifugation $(1,000 g)$.

Swelling power and solubility. A $1.25 \%(\mathrm{w} / \mathrm{v})$ starch suspension was heated during $30 \mathrm{~min}$ at specific temperatures $\left(60,70,80\right.$ and $\left.90^{\circ} \mathrm{C}\right)$ and after this, the starch paste produced was recovered by mild centrifugation $(1,000 \mathrm{~g} \quad \mathrm{x} \quad 15 \mathrm{~min}$.).
Swelling power was measured as water binding capacity and solubility was based on soluble sugars (Leach et al, 1959; Wosiacki \& Cereda, 1989).

Chestnut starch pastes. Pastes were made submitting the starch slurry to controlled heat until the system reached the temperature of $95^{\circ} \mathrm{C}$. In all cases starch moisture was considered to achieve the desired concentration. Corn and cassava starch pastes were used as controls. The methodology used to analyze the functional properties of starch pastes was described by Cereda \& Wosiacki (1985).

Paste clarity. A 5\% (w/v) chestnut starch paste was poured onto petri dishes in order to evaluate the clarity as compared with that of cassava and corn starches. To intensify the observation, a dark sheet of paper was set partially under the dishes to provide a clear and dark contrast (Wosiacki \& Cereda, 1989).

Paste elasticity. A 5\% (w/v) chestnut starch paste was poured onto petri dishes in order to evaluate the elasticity as compared with that of cassava and corn starches. To observe the deformation when a spatula was driven through the paste, an ink line was drawn over the surface; as the spatula advances the colored line is deformed just like the paste (Wosiacki \& Cereda, 1989; Kite et al., 1963). Result was recorded by touching the paste surface with a filter paper sheet. After removing the adherent starch paste, the paper was dried and stored as a photocopy.

Gel strength. Different concentrations (5, 6 and $7 \%(\mathrm{w} / \mathrm{v}))$ of chestnut starch pastes were poured onto $50 \mathrm{ml}$ glass mold and after cooling, were removed and left over a smooth surface. Gel strength was evaluated according to the capability to maintain the shape similar to that of the recipient cup (Wosiacki \& Cereda, 1989). In order to compare gel strength among different starches the $7 \%$ paste was selected. Results were recorded as $\mathrm{B} \& \mathrm{~W}$ pictures.

Viscographic analysis. A $6 \%(\mathrm{w} / \mathrm{v})$ chestnut starch suspension in $0.05 \mathrm{M}$ sodium acetate buffer at $\mathrm{pH} 6.0$ was analyzed with a Brabender ${ }^{\mathrm{TM}}$ viscoamylograph at constant heating and cooling rates. The equipment was able to increase the temperature and to rotate the vessel at a fixed rate 
$\left(1.5^{\circ} \mathrm{C} / \mathrm{min}\right.$. and $75 \mathrm{rpm}$, respectively) with a 700 cmg sensitivity cartridge, usual for starch analysis. Total procedure included an initial heating phase, from 50 to $95^{\circ} \mathrm{C}$, in order to observe the viscosity features. Then a subsequent phase maintaining the whole system at $95^{\circ} \mathrm{C}$ during $30 \mathrm{~min}$ to observe the paste resistance to mechanical stirring and the final cooling phase to $50^{\circ} \mathrm{C}$ to observe the retrogradation. The influence of the starch concentration from 5 to $8 \%(\mathrm{w} / \mathrm{v})$ and of the $\mathrm{pH}$ from 3 to 6 was also studied. Results were recorded directly from the equipment as viscoamylograms (Mazurs et al, 1957; Radley, 1976).

Freeze -thaw cycles. A 5\% (w/v) starch paste was used to evaluate the stability up to four freezethaw cycles $\left(18^{\circ} \mathrm{C} / 6 \mathrm{~h}\right)$. Water removal after thawing was measured gravimetrically (Singhal \& Kulkarni, 1990).

Paste enzymatic susceptibility. The determination of reducing sugars (Somogyi, 1945; Nelson, 1944) and glucose (Dahlquist, 1961) were used to evaluate the susceptibility of the starch pastes to hydrolysis as well as viscosity drop observed in Brabender visco-amylograph during the first $30 \mathrm{~min}$ heating phase, from 50 to $95^{\circ} \mathrm{C}$ (Goering \& Brelsford, 1965; Pazur, 1965; Rosenthal \& Espindola, 1969; Vijayogapal et al, 1988). Suitable diluted commercial microbial $\alpha$ amylase was used in a $6 \mathrm{~g} / 100 \mathrm{ml}$ chestnut starch in $0.05 \mathrm{M}$ sodium acetate buffer at $\mathrm{pH} 6$. Vegetal amylases were obtained from a suspension of malted wheat $(2 \mathrm{~g} / 100 \mathrm{ml}$ - five $\mathrm{ml}$ of the clear extract was considered 100\%) and used in the same way.

\section{RESULTS AND DISCUSSION}

The analyzed nuts had a semi-spherical shape, with a planar face and a base distinct from the apex, resembling slightly as a water drop. There was not a symmetric axis in the nuts what suggested, in some aspects, that some difficulty might be observed in processing equipment (Fig. 1). It was difficult to handle the spiny fruits and also to remove the cellulose hull in ordinary conditions without cooking. Edible fraction represented $80.0 \% \pm 3.9$, with a coefficient of variation of $4.9 \%$. The non edible fraction was represented mainly by the hulls. The water content of peeled nuts was $52.2 \mathrm{~g} / 100 \mathrm{~g}$ and that of the hulls, 34.5g/100g. This suggested that sweet chestnut might represent an interesting raw material for industrial purposes. The chestnuts had a weight distribution from 4 to $27 \mathrm{~g}$, with an average weight of $14.0 \mathrm{~g}$. Most of the 70 nuts were found to range from 11 to $17 \mathrm{~g}$. Chemical composition of the chestnut flour is shown in Table 1 .

Table 1 - Chemical Composition of Starchy Flours

\begin{tabular}{lccc}
\hline $\begin{array}{l}\text { Fraction, } \\
\text { g/100 g }\end{array}$ & $\begin{array}{c}\text { Chestnut } \\
\text { flour }\end{array}$ & $\begin{array}{c}\text { Corn } \\
\text { flour* }\end{array}$ & $\begin{array}{c}\text { Cassava } \\
\text { flour** }\end{array}$ \\
\hline Ash & 2.14 & 1.73 & 3.17 \\
Lipid & 5.39 & 5.20 & 0.53 \\
Fiber & 2.34 & 2.89 & 3.29 \\
Protein & 5.58 & 10.40 & 2.80 \\
Starch & 78.75 & 79.78 & 90.21 \\
\hline
\end{tabular}

Ref.: *Camargo et al, 1984; **Cereda, 1994.

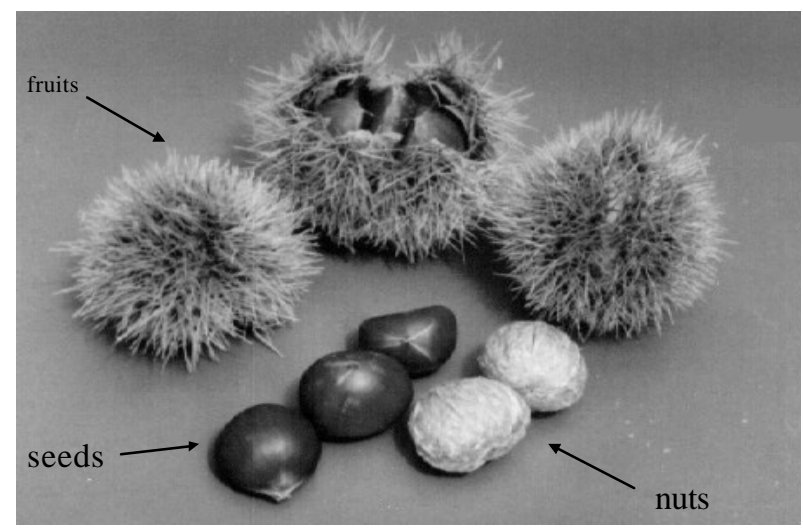

Figure 1 - Some aspects of sweet chestnuts.

It was possible to observe that the chestnut flour showed some similarity with corn flour, especially in terms of ash, lipid and fiber, differing from that of cassava. The content of protein from chestnut flour was half of that from corn but twice that from cassava flour. All the three flours showed high contents of starch; chestnut starch had a peculiar chemical composition when compared with other starches, showing higher contents of ash, lipid, fiber and protein (Table 2).

Table 2 - Chemical Composition of Starches

\begin{tabular}{lrcc}
\hline $\begin{array}{l}\text { Fraction, } \\
\mathrm{g} / 100 \mathrm{~g}\end{array}$ & Chestnut & Corn & Cassava \\
\hline Ash & 0.51 & 0.02 & 0.16 \\
Lipid & 1.51 & 0.06 & 0.43 \\
Fiber & 1.09 & n.a. & n.a. \\
Protein & 0.83 & 0.30 & 0.08 \\
Starch & 96.06 & 99.62 & 99.32 \\
\hline
\end{tabular}

n.a.: not analyzed 
Wankhede et al. (1977), studying the starch from groundnut seeds found high content of protein even after purification. Amylose content of chestnut starch $(21.5 \%)$ was intermediary to that of corn (24.5\%) and cassava (18.6\%), what strongly suggested distinct granular features and functional properties (Table 3).

Table 3 - Amylose and amylopectin contents

\begin{tabular}{lrrr}
\hline & Chestnut & Corn & Cassava \\
\hline Blue value & 0.98 & 1.08 & 0.87 \\
Amylose \% & 21.50 & 24.50 & 18.60 \\
Amylopectin & 78.80 & 75.50 & 81.40 \\
$\%$ & & & \\
\hline
\end{tabular}

Park et al. (1982) studied the properties of starch of Castanea crenata, including pasting temperature, that was 55 to $60^{\circ} \mathrm{C}$ and they observed that the paste was stable against heating and shear force. Starch granules had irregular oval shape with the size of 2.9 to $21.4 \mu \mathrm{m}$. Takeda et al. (1987) also studied some characteristics of Castanea crenata starch and concluded that pasting temperature was $64.5^{\circ} \mathrm{C}$ and amylose content $19.6 \%$.

In this report, chestnut starch granular solubility in DMSO (40.8\%) was similar to that of cassava starch granules (45.4\%) but lower than that of corn granules solubility (91.3\%). This could be due to structural affinity for the solvent and it was an indicator of granular binding strength and homogeneity (Paramahans et al, 1980). Groundnut seed starch was resistant to DMSO treatment indicating the presence of strong and homogeneous bonding forces within the granules as observed for lablab and jack bean starches (Wankhede et al., 1977). In Figure 2 the shape and size of native starch granules are shown.

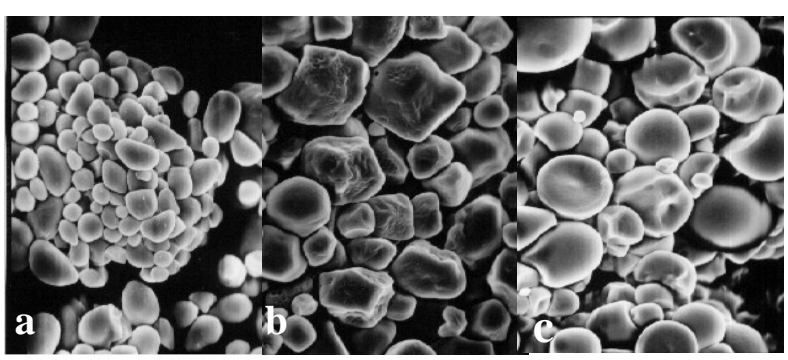

Figure 2 - Native starch granules: (a) chestnut, (b) corn and (c) cassava.

As can be observed, the chestnut starch granules are smaller than that of corn and cassava. The SEM results showed that enzymatic hydrolysis occurred on the surface of cassava starch, but there was not evidence of corrosion, like in corn starch granules (Franco et al, 1988). Granular cereal starches are more susceptible to enzymatic hydrolysis than root and tuber starches, even though cassava starch granules liberate considerable amounts of sugars when exposed to amylolytic enzymes (Rickard et al,.1990). The results are shown in Figure 3.

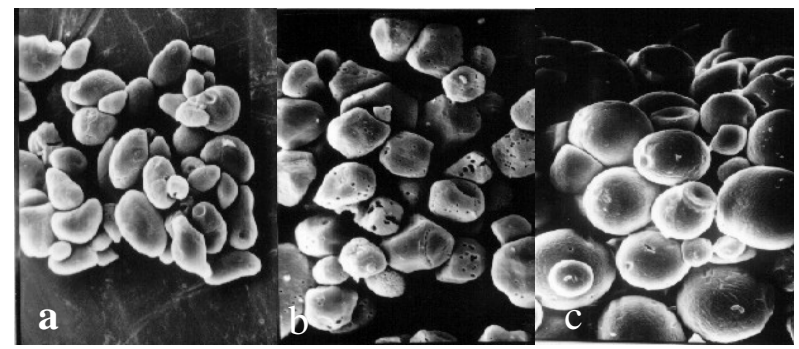

Figure 3 - Starch granules treated with vegetal amylases: (a) chestnut, (b) corn and (c) cassava.

All the three starches have peculiar morphology, and it was possible to observe that corn starch granules were more susceptible to enzyme action than chestnut and cassava starch granules. According to Fuwa et al. (1979), Chinese chestnut starch granules were also more resistant to enzymatic hydrolysis than corn starch. This low granular susceptibility to enzymatic hydrolysis is proper of root and tuber starches (Rickard et al., 1990).

The solubility and the swelling power of native and fermented chestnut starches as well as the solubility : swelling power ratio are shown in Table 4.

Table 4 - Swelling power and solubility of native and fermented chestnut starch.

\begin{tabular}{ccccccc}
\hline \multicolumn{3}{c}{ Tempera.ture, ${ }^{\circ} \mathrm{C}$} & Native & \multicolumn{3}{c}{ Fermented } \\
\hline & $\mathrm{S}$ & $\mathrm{SP}$ & $\mathrm{R}$ & $\mathrm{S}$ & $\mathrm{SP}$ & $\mathrm{R}$ \\
60 & 0.6 & 3.3 & 0.19 & 0.6 & 4.4 & 0.13 \\
70 & 15.9 & 23.8 & 0.67 & 13.1 & 14.6 & 0.90 \\
80 & 23.4 & 27.2 & 0.86 & 25.3 & 23.3 & 1.09 \\
90 & 29.4 & 34.7 & 0.85 & 32.9 & 23.7 & 1.39
\end{tabular}

Solubility (S), Swelling power (SP) and Solubility : swelling ratio $(\mathrm{R})$

As can be seen, native and fermented chestnut starch showed a similar solubility pattern but when swelling power was considered, the values for the fermented starch were lower. The chestnut starch in water, from 60 to $90^{\circ} \mathrm{C}$, resembled that of cassava starch, showing a significant liberation of soluble components of the granules. The solubility 
of corn starch granules was lower and could be described as a 2-stage type: only at temperatures over $80^{\circ} \mathrm{C}$ it could be observed at a low value, around 50\% comparing with other starches.

The same was observed concerning swelling power. If both characteristics were considered, as the solubility : swelling ratio, chestnut granules showed an intermediate position when compared with reference starches. Swelling power and solubility of groundnut starch granules were not as high as for corn or potato starches, what indicated the presence of relatively strong bonding forces within the granules (Wankhede et al., 1977).

Indicators of quality of the reference starches, corn and cassava, are shown in Table 5.

Table 5 - Corn and cassava starches swelling power and solubility.

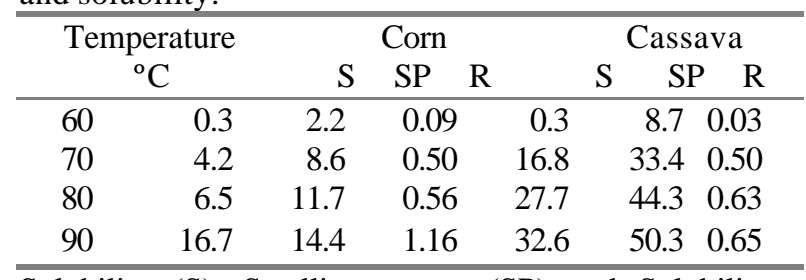

Solubility (S), Swelling power (SP) and Solubility : Expansion ratio (R)

The experiments concerning functional properties of the chestnut starch indicated some similarities with corn or cassava starches. Chestnut starch paste presented a stringy rheology, like cassava starch paste and gel strength is quite similar to corn gel strength.

The critical concentration for chestnut starch gel formation seemed to be $7 \%(\mathrm{w} / \mathrm{v})$, and the influence of starch concentration in the formation are shown in Figure 4.

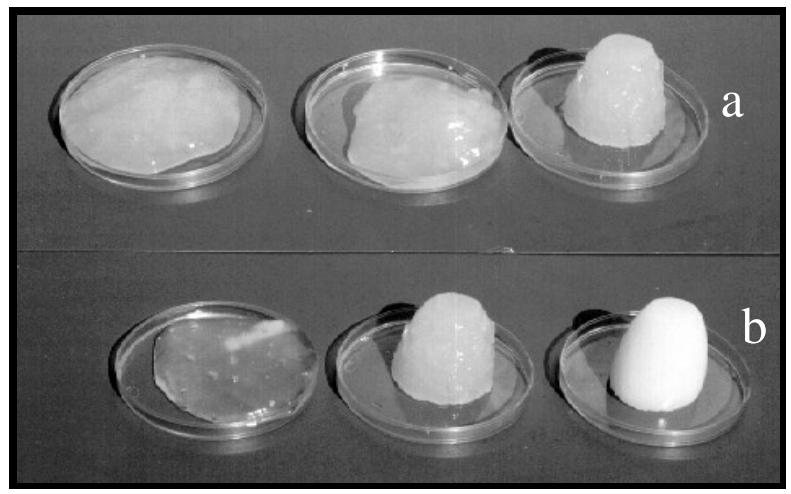

Figure 4 - Chestnut starch gel strength as influenced by concentration (a) 5, 6 an 7\% and (b) 7\% chestnut starch gel as compared with cassava (left) and corn (right).
Chestnut starch presented a viscographic pattern where a relative low pasting temperature and low tendency to retrogradation were observed, and this resembled cassava starch pattern. On the other hand, absence of a well defined viscosity peak and its cooking stability resembled corn starch. At low concentrations of chestnut starch, it resembled corn starch viscographic pattern, whereas at high concentrations it resembles cassava. Chestnut starch pastes were stable up to $\mathrm{pH} 4.0$ without significant changes on viscographic pattern, but below this $\mathrm{pH}$ value, the paste showed a pronounced cooking instability.

The paste also showed an intermediary pattern in terms of clarity when compared with corn and cassava pastes. In hot conditions $\left(95^{\circ} \mathrm{C}\right)$ the paste of cassava starch was completely transparent and in cold conditions $\left(50^{\circ} \mathrm{C}\right)$ the paste of corn starch was quite opaque. In both conditions, however, chestnut starch paste was translucent.

Freeze-thawing stability is an important aspect concerning characterization of starches. In Table 6 the amount of water liberation from each starch paste is shown.

Table 6 - Water liberation due to freeze-thaw cycles.

\begin{tabular}{cccc}
\hline Cycles & \multicolumn{3}{c}{ Water liberation of pastes, $\mathrm{g} / 100 \mathrm{~g}$} \\
& Chestnut & Corn & Cassava \\
\hline 1 & 17.8 & 29.3 & 0.0 \\
2 & 68.0 & 70.2 & 9.7 \\
3 & n.a. & n.a. & 23.8 \\
4 & n.a. & n.a. & 27.1 \\
\hline
\end{tabular}

n.a.: not analyzed

Chestnut starch paste presented a behavior quite similar to that of corn paste being very susceptible to freeze-thawing, whereas cassava starch paste was more resistant.

The influence of commercial grade microbial amylases on the starch pastes was observed considering pasting temperature and maximum viscosity and the results are shown in Table 7.

Table 7 - Effect of commercial grade microbial amylases in viscographic characteristics of the starch pastes.

\begin{tabular}{lllllll}
\hline Features & \multicolumn{2}{c}{ Chestnut } & \multicolumn{2}{c}{ Corn } & \multicolumn{3}{c}{ Cassava } \\
& $\mathrm{a}$ & $\mathrm{b}$ & $\mathrm{a}$ & $\mathrm{b}$ & $\mathrm{a}$ & $\mathrm{b}$ \\
\hline Pasting, ${ }^{\circ} \mathrm{C}$ & 69.5 & 69.5 & 81.5 & 77.5 & 61.1 & 60.8 \\
Visc.max., & 630 & 380 & 375 & 260 & 880 & 380 \\
BU & & & & & & \\
$\begin{array}{l}\text { Viscosity, } \\
\text { 95 } 630\end{array}$ & 230 & 375 & 220 & 545 & 10 \\
\hline $5^{\circ} \mathrm{C}$ & & & & & & \\
\hline
\end{tabular}

a: control, b: treatment 
All the three starch pastes maintained their pasting temperature although corn starch paste showed small difference. The maximum viscosity, however, dropped down to 60,70 and $43 \%$ for chestnut, corn and cassava starch pastes, respectively. The decrease in the viscosity at $95^{\circ} \mathrm{C}$ was 63,41 and $99 \%$, for starch pastes of chestnut, corn and cassava, respectively. The influence of wheat amylases on the starch pastes was observed by considering pasting temperature and maximum viscosity (Table 8).

Table 8 - Effect of wheat amylolytic enzymes on viscographic characteristics of the pastes.

\begin{tabular}{lccl}
\hline $\begin{array}{c}\text { Starch paste } \\
\text { Source }\end{array}$ & $\begin{array}{c}\text { Extract } \\
\% \\
(\mathrm{v} / \mathrm{v})\end{array}$ & $\begin{array}{c}\text { Viscosity } \\
\text { max. } \\
(\mathrm{BU})\end{array}$ & $\begin{array}{l}\text { Pasting } \\
\text { temperature } \\
\left({ }^{\circ} \mathrm{C}\right)\end{array}$ \\
\hline Chestnut & 0 & 545 & 69.5 \\
& 10 & 330 & 69.5 \\
& 20 & 95 & 69.5 \\
Corn & 50 & 5 & 69.5 \\
& 0 & 290 & 84.5 \\
& 10 & 165 & 80.8 \\
Cassava & 50 & 80 & 76.3 \\
& 100 & 20 & 74.8 \\
& 0 & 900 & 64.0 \\
& 10 & 100 & 64.0 \\
\hline
\end{tabular}

The pasting temperature of chestnut starch was maintained with this treatment. Corn starch paste showed a small decrease of around $11 \%$; pasting of cassava starch was not detected anymore when $20 \%$ extract was studied. Maximum viscosity of the pastes were also modified, with a drop down to 1 and to 7\%, for chestnut and corn starch pastes, respectively; cassava starch paste was indeed not even formed. The influence of amylases on viscographic behavior of the starch pastes was further observed. The chestnut starch paste showed the same pasting temperature in both cases, with and without enzymes, but the paste did not reach high viscosity at $95^{\circ} \mathrm{C}$; so, as the granules swollen the enzymes were able to attack the soluble polysaccharides. The corn starch paste showed a drop in the pasting temperature and also a new viscographic pattern what suggested that internal cohesive forces fell down. The cassava starch showed a new pattern somewhat similar to that of chestnut starch but with higher maximum viscosity. Levels of reducing sugars and glucose, were very similar when chestnut and cassava pastes were compared; liberation of sugar from corn starch paste was more limited, as can be observed in Table 9.
European chestnut starch composition resembled that of cereal starches in relation to amylose : amylopectin ratio and the presence of minor compounds like lipid and protein. Its granules presented peculiar shapes, different from that of corn and cassava, being smaller and having intermediate enzymatic susceptibility as compared with the controls - corn granular starch was more susceptible than cassava granular starch, as observed in SEM pictures. Swelling power and

Table 9 - Reducing sugar and glucose content of starch pastes as influenced by germinated wheat extract.

\begin{tabular}{lccc}
\hline $\begin{array}{c}\text { Starch paste } \\
\text { Source }\end{array}$ & $\begin{array}{c}\text { Extract } \\
\% \\
(\mathrm{v} / \mathrm{v})\end{array}$ & $\begin{array}{c}\text { Reducing } \\
\text { sugar, } \\
\mathrm{g} / 100 \mathrm{ml}\end{array}$ & $\begin{array}{c}\text { Glucose, } \\
\mathrm{g} / 100 \mathrm{ml}\end{array}$ \\
\hline Chestnut & 10 & 0.7 & 0.03 \\
& 30 & 2.8 & 0.10 \\
& 50 & 6.1 & 0.30 \\
Corn & 100 & 11.1 & 1.00 \\
& 10 & 0.6 & 0.06 \\
& 30 & 2.2 & 0.20 \\
Cassava & 50 & 2.8 & 0.20 \\
& 100 & 5.0 & 0.30 \\
& 10 & 1.0 & 0.20 \\
& 30 & 3.4 & 0.40 \\
& 50 & 8.2 & n.a. \\
n.a.: not analyzed & 100 & 12.3 & 1.20 \\
& & &
\end{tabular}

solubility of chestnut starch were intermediate to those of cassava and corn starches, at any temperature tested. Chestnut starch has peculiar functional properties. The characteristics of elasticity, pasting and retrogradation were similar to that found in cassava starch and considering cooking stability, maximum viscosity, paste clarity and gel strength was more related to corn starch.

Studying some characteristics of Amaranthus paniculatus (L.) starch, Modi \& Kulkarni (1976) observed that there was a relation between its high solubility and the high content of amylopectin, when compared with corn starch; they also observed that gelatinization temperature was high due to small starch granules. High viscosity peak, indicating high swelling power of the granules, was also linked with amylopectin content. As a conclusion, it was observed that Amaranthus starch was better than corn starch in order to obtain high viscosity pastes by mild heating since it gave more viscous pastes at low temperatures. Due to its high content of amylopectin, this paste had a minimum setback during cooling.

Commercial grade $\alpha$-amylase treatment did not affect the pasting temperature of chestnut starch as 
well as observed for cassava starch but caused a maximum viscosity drop down to around 50\%; at $95^{\circ} \mathrm{C}$, viscosity was even more depressed. This was not the case for corn starch, since drop in both pasting temperature and viscosity were observed. Germinated wheat enzymes also caused a similar behavior and chestnut starch paste again seemed to be more related to cassava starch; the liberation of reducing sugar as well as glucose was higher for them when compared with corn starch paste.

\section{ACKNOWLEDGEMENTS}

The authors are grateful to CNPq and RHAE program for financial support and scholarship.

\section{RESUMO}

A composição química das castanhas mostrou níveis elevados de amido, sendo o principal componente da matéria seca. $\mathrm{O}$ teor de umidade das castanhas foi de aproximadamente $50 \mathrm{~g} / 100 \mathrm{~g}$ e o conteúdo de amido da farinha de castanha foi de cerca de $80 \mathrm{~g} / 100 \mathrm{~g}$; outros componentes da farinha de castanha são proteínas $(5,58 \mathrm{~g} / 100 \mathrm{~g})$, lipídios $(5,39 \mathrm{~g} / 100 \mathrm{~g})$, fibra bruta $(2,34 \mathrm{~g} / 100 \mathrm{~g})$ e cinzas $(2,14 \mathrm{~g} / 100 \mathrm{~g})$. A fração amido foi caracterizada quimicamente de forma a identificar a qualidade dos grânulos comparando-os com os de amido de milho e de mandioca. $\mathrm{O}$ amido foi obtido mediante procedimentos convencionais de extração e purificação e continha mais lipídios e proteínas do que os amidos usados como controle. Os grânulos do amido de castanha apresentam forma peculiar, menores do que os amidos controles. A composição química com relação à razão amilose/amilopectina foi intermediária àquela encontrada para os amidos de milho e de mandioca. O poder de inchamento e a solubilidade a diferentes temperaturas apresentaram valores intermediários embora mais próximos aos apresentados por grânulos do amido de mandioca. O mesmo comportamento foi observado com relação à solubilidade em dimetilsulfóxido (DMSO). Os grânulos, tratados enzimaticamente com amilase bacteriana comercial e também com extrato de trigo germinado, foram observados por microscopia eletrônica de varredura (SEM). Suspensões de grânulos de amido de castanha em água foram aquecidas e as pastas pesquisadas comparativamente com aquelas obtidas com amido de milho e de mandioca. As pastas obtidas com amido de castanha mostraram perfis característicos com viscosidade inicial elevada mas com ausência de pico, resistência à agitação mecânica sob temperatura elevada $\left(95^{\circ} \mathrm{C}\right)$ e viscosidade final elevada. As pastas de amido de castanha apresentaram-se estáveis até pH 4,0 e instáveis a pH 3,0. A perda de água observada na pasta de amido de castanha após ciclos de congelamento / descongelamento foi mais relacionada ao comportamento da pasta de amido de milho assim como a transparência e a força do gel. De uma forma geral os resultados mostraram que as pastas de castanha apresentam propriedades funcionais com valores intermediários se comparadas com as obtidas com amidos de milho e de mandioca.

\section{REFERENCES}

Alexander, R.J. (1996), New starches for food applications. Cereal-Foods-World, 41, 796-798.

American Maize Products Co. (1983), New starches for spoonable salad dressings. Food Processing, 44, $21-$ 22.

AOAC - Association of Official Agricultural Chemists. (1965), Official Methods of Analysis 10.ed. AOAC, Washington.

Brouk, B. (1975), Plants consumed by man. Academic Press, London, 479p.

Camargo, R.; Fonseca, H.; Graner, M. et al. (1984), Tecnologia dos Produtos Agropecuários -_Alimentos. Nobel, São Paulo, 284 p.

Cereda, M.P. (1994), Resíduos da Industrialização da Mandioca no Brasil. Paulicéia, São Paulo, 174p.

Cereda,M.P.; Wosiacki,G. (1985), Characterization of Pinhão Starch. Part I. Extraction and Properties of the Starch Granules. Starch/Stärke, 37, 224-227.

Dahlquist, A. (1961), Determination of maltase and isomaltase activities with a glucose oxidase reagent. Biochem. J., 80, 547-551.

Demiate, I.M., Senger, S.A., Vogler, Z., Cereda, M.P., Wosiacki, G. (1997a), Characteristics of quality of sour starch samples produced or commercialized in Paraná State. Arquivos de Biologia e Tecnologia, 40, 321-330.

Demiate, I.M., Souza, T.O.; Pugsley, S.; Wosiacki, G. (1997b), Características de qualidade de amostras de polvilho azedo. Parte 2 - Estado de Santa Catarina. Agrop. Catarinense, 10, 51-57.

Dubois, M., Gilles, K.A., Hamilton, J.K., Rebers, P.A., Smith, F. (1956), Colorimetric method for determination of sugars and related substances. Anal. Chem., 28, 350-356. 
Fuwa, H.; Sugimoto, Y.; Takaya, T. (1979), In vivo and in vitro degradation of starch granules by starchdegrading enzymes. Journal of the Japanese Society of Starch Science, 26, 105-111.

Goering, K.J.; Brelsford, D.L., (1965), Barley starch. II. Some properties of barley starch. Cereal Chemistry, 42, 15-24.

Hatanaka, Y.; Inaoka, K.; Özboy, O.; Demiate, I.M.; Kobayashi, O.; Higashihara, M.; Hyiama, K. (1997), Study of some properties of starch isolated from halotolerant microalgae Dunaliella. J. Appl. Glycosci., 44, 515-522.

Hippleheuser, A. (1994), What starch is best? New starches permit new flavor intensities. Food Marketing \& Technology, 8, 25-26.

Izquierdo, A.J. (1978), El Castaño Arbol Frutal. Hojas Divulgadoras (Madrid) 23-24.

Kite, F.E.; Maywald, E.C.; Schoch,T.J. , (1963), Funktionalle Eigenschaften von Lebensmittelstärken. Starch/Stärke, 15, 131-138.

Franco, C.M.R.; Ciacco, C.F., Tavares, D.Q. (1988), Studies on the susceptibility of granular cassava and corn starches to enzymatic attack. Part 2. Studies of the granular structure of starch. Starch/Stärke, 40, 2932.

Leach, H.W.; Schoch, T.J. (1962), Structure of the starch granule. III - Solubilities of granular starches in dimethylsulfoxide. Cereal Chemistry, 39, 318327.

Leach, H.W.; Mccowen, L.D.; Schoch, T.J. (1959), Structure of the starch granules. I - Swelling and solubility pattern of various starches. Cereal Chemistry, 36, 533-544.

Loesche, K. (1990), Functional properties of new kinds of food raw materials. Lebensmitteltechnik, 22, 482484; 487-488; 490-491.

Mauro, D.J. (1996), An update on starch. CerealFoods-World, 41, 776-780.

Mazurs, E.G.; Schoch, T.J.; Kite, F.E. (1957), Graphical analysis of the Brabender viscosity curves of various starches. Cereal Chemistry, 34, 141-152.

Mestres, C.; Boungou, O.; Zakhia, N.; Rouau, X.; Faure, J. (1996), Comparison of the ability of fermented maize flour and cassava starch for making bread-like products. Paper presented at AACC Anual Meeting, Sept. 15-19, Baltimore. (Poster 80).

Modi, J.D.; Kulkarni, P.R. (1976), New starches: the properties of the starch from Amaranthus paniculatus (L.). Acta Alimentaria, 5, 399-402.

Morrison, W.R.; Laignelet, B. (1983), An improved colorimetric procedure for determining apparent and total amylose in cereal and other starches. Journal of Cereal Science, 1, 9-20.

Nelson, H.(1944), A photometric adaptation of the Somogyi method for determination of glucose. Journal of Biological Chemistry, 153, 375-380.
Paramahans, S.V.; Wankhede, D.B.; Tharanathan, R.N.(1980), Studies on varagu starch. Starch/Stärke, 32, 109-112.

Park, I.S.; Kim, S.K.; Kim, C.S. (1982), Physicochemical properties of chestnut starch. Journal of the Korean Agricultural Chemical Society, 25, 218-223.

Patil, S.K. (1994), New hybrids - new starches. World of ingredients, 56-57.

Pazur, J.H.(1965), Enzymes in synthesis and hydrolysis of starch. In: Whistler, R.L. \& Paschall, E.F. (eds.) Starch: chemistry and technology. Academic Press, New York, p.133-171.

Radley, J.A. (1976), Physico-chemical methods of characterizing starch. In: Radley, J.A.(ed.) Examination and analysis of starch and starch products. Applied Science Publishers, London, p.91132.

Rickard, J.E.; Asaoka, M., Blanshard,M.V. (1990), The physico-chemical properties of cassava starch. Tropical Science, 31, 189-207.

Rosenthal, F.R.T.; Espindola, L. (1969), The mucuna (Dioclea malocarpa) Starch. Die Stärke, 21, 262-266.

Rutter, P.A., Müller, G.; Payne, J.A. (1991), Chestnuts (Castanea). Genetic Resources of Temperate Fruit and Nut Crops. Acta Horticulturae, 290, 761-785.

Singhal, R.S.; Kulkarni, P.R. (1990), Some properties of Amaranthus paniculatus (Rajgeera) starch pastes. Starch/Stärke, 42, 5-7.

Smith, P.S. (1975), New starches; a key to new products and lower costs for the confectioner. Manufacturing Confectioner, 55, 55-59.

Smith, P.S.; Bell, H. (1986), New starches for food applications. Cereal-Foods-World, 31, 724-726.

Somogyi, M. (1945), Determination of blood sugar. $J$. Biol. Chem., 160, 69-73.

Stockwell, A.C. (1995), Some current developments in technology-assisted breeding. Cereal-Foods-World, 40, 7-10.

Takeda, C.; Takeda, Y.; Hizukuru, S. (1987), Structure and properties of chestnut starch. Journal of the Japanese Society of Starch Science, 34, 31-37.

Vijayogapal, K.; Balagopalan, C.; Moorthy, S.N. (1988), Gelatinization and liquefaction of cassava flour: effect of temperature, substrate and enzyme concentrations. Starch/Stärke, 40, 300-302.

Wankhede, D.B.; Saroja, R.; Raghavendra, M.R. (1977), New starches. Preparation and properties of starch and its fractions of two varieties of groundnuts. Die Stärke, 29, 223-228.

Wosiacki, G.; Cereda, M.P. (1985), Characterization of pinhão starch. Part I. Extraction, physical and chemical propertis of the starch fraction. Starch/Stärke, 37, 224-227. 
Wosiacki, G.; Cereda, M.P. (1989), Characterization of pinhão starch. Part III - Hydration of the granules and susceptibility to enzymatic hydrolysis. Starch/Stärke, 41, 327-330.
Zallie, J. (1988), New starches for gelling and nongelling applications. Manufacturing-Confectioner, 68, 99-104.

Received: August 12, 1997;

Revised: December 17, 1997;

Accepted: May 30, 2000. 